\title{
Modified sewing machine technique in combination with lens aspiration and anterior vitrectomy for large iridodialysis repair
}

Iu Kwang Kwok ${ }^{2}$, Nadia Yaacob ${ }^{1,2}$, Sylves Patrick ${ }^{1,2,3}$, Azhany Yaakub ${ }^{1,2}$

${ }^{1}$ Department of Ophthalmology \& Visual Science, School of Medical Sciences, Health Campus, Universiti Sains Malaysia, Kubang Kerian, Kelantan, Malaysia; ${ }^{2} \mathrm{Hospital}$ Universiti Sains Malaysia, Health Campus Universiti Sains Malaysia, Kubang Kerian, Kelantan, Malaysia; ${ }^{3}$ Department of Surgery, School of Medical Sciences, Universiti Malaysia Sabah, Kota Kinabalu, Sabah, Malaysia

\section{Abstract}

We describe the management of a large iridodialysis repair using the modified sewing machine technique and lens aspiration in a single setting in an eye with blunt ocular injury. We performed the lens aspiration first followed by iridodialysis repair. The technique was easy and fast, with good postoperative anatomical outcome.

Keywords: iridodialysis, modified sewing machine technique, traumatic cataract

Correspondence: Dr. Yaakub Azhany, Department of Ophthalmology \& Visual Science, School of Medical Sciences Health Campus, Universiti Sains Malaysia, 16150 Kubang Kerian, Kelantan Malaysia.

E-mail: azhany@usm.my 


\section{Teknik mesin jahit yang diubah suai dalam pembedahan kombinasi aspirasi kanta dan vitrektomi anterior untuk pembaikian iridodialisis yang besar}

\section{Abstrak}

Kami menerangkan rawatan pembaikian iridodialisis besar menggunakan teknik mesin jahit yang diubah suai dengan aspirasi kanta dalam satu masa pembedahan pada mata yang mengalami kecederaan okular tumpul. Kami melakukan aspirasi lensa terlebih dahulu diikuti dengan pembaikian iridodialisis. Tekniknya mudah dan cepat, dengan hasil anatomi pasca operasi yang baik.

Kata kunci: iridodialisis, katarak trauma, teknik mesin jahit yang diubah suai

\section{Introduction}

Iridodialysis is defined as the separation of the iris from its root at the ciliary body. It commonly occurs due to blunt trauma or following complicated intraocular surgery. A large iridodialysis can lead to monocular diplopia, glare, photophobia, or cosmetic disfigurement, all of which require surgical intervention. The surgical approaches are broadly categorized into the open- and closed-chamber methods (Table 1). ${ }^{1-7}$ In this article, we present a case of combined lens aspiration and anterior vitrectomy together with a large iridodialysis repair using a modified sewing machine technique.

\section{Results}

A 21-year-old man alleged blunt trauma following a grinding incident. The patient developed sudden loss of vision in the left eye and experienced severe eye pain. Visual acuity was reduced markedly in the left eye (light perception in all quadrants). The cornea was slightly hazy with a central epithelial defect. There was a large iridodialysis extending from the 9 o'clock to the 3 o'clock positions, with the detached iris folded inferiorly and obscuring most of the pupil (Fig. 1). The lens was cataractous with a breached anterior capsule superiorly. Minimal lens material was seen in the anterior chamber with no obvious prolapse of the vitreous. 
Table 1. Summary of literature review of techniques for iridodialysis repair

\begin{tabular}{|c|c|c|c|}
\hline Study & Authors & Instrumentation & Technique \\
\hline $\begin{array}{l}\text { Sewing } \\
\text { machine } \\
\text { technique for } \\
\text { iridodialysis } \\
\text { repair }\end{array}$ & $\begin{array}{l}\text { Kumar et } \\
\text { al. }(2014)^{1}\end{array}$ & $\begin{array}{l}\text { 26-G needle } \\
\text { 10/0 prolene suture } \\
20-G \text { MVR blade }\end{array}$ & $\begin{array}{l}\text { Passage of the needle through } \\
\text { the peripheral iris and sclera from } \\
\text { inside out. } \\
\text { Multiple external loops are formed } \\
\text { and each loop is cut and tied. }\end{array}$ \\
\hline $\begin{array}{l}\text { Cobbler's } \\
\text { technique for } \\
\text { Iridodialysis } \\
\text { Repair }\end{array}$ & $\begin{array}{l}\text { Pandav et } \\
\text { al. }(2016)^{2}\end{array}$ & $\begin{array}{l}100 \text { prolene suture } \\
26-G \text { needle }\end{array}$ & $\begin{array}{l}\text { Multiple loops are formed: the } \\
\text { free end of the suture is passed } \\
\text { through the loops and tied to form } \\
\text { a single knot. }\end{array}$ \\
\hline $\begin{array}{l}\text { New technique } \\
\text { for iridodialysis } \\
\text { correction: } \\
\text { single-knot } \\
\text { sewing- } \\
\text { machine suture }\end{array}$ & $\begin{array}{l}\text { Silva et al. } \\
(2016)^{3}\end{array}$ & $\begin{array}{l}\text { 9-0 non-absorbable } \\
\text { suture } \\
27-G \text { plastic-handled, } \\
40 \mathrm{~mm} \text { straight } \\
\text { needle }\end{array}$ & $\begin{array}{l}\text { Multiple loops formed; the loops } \\
\text { are secured with an auxiliary } \\
\text { anchoring suture. In the last loop, } \\
\text { the end of the suture is retrieved } \\
\text { and tied to the one obtained in the } \\
\text { first loop and the auxiliary suture } \\
\text { is removed. }\end{array}$ \\
\hline $\begin{array}{l}\text { Knotless } \\
\text { technique for } \\
\text { iridodialysis } \\
\text { repair }\end{array}$ & $\begin{array}{l}\text { Voykov et } \\
\text { al. }(2015)^{5}\end{array}$ & $\begin{array}{l}\text { Double-armed } 10-0 \\
\text { prolene suture } \\
\text { Bent } 27-G \text { needle }\end{array}$ & $\begin{array}{l}\text { Prolene suture is secured in the } \\
\text { sclera using a zigzag shaped intra- } \\
\text { scleral suture (Z-suture). }\end{array}$ \\
\hline
\end{tabular}

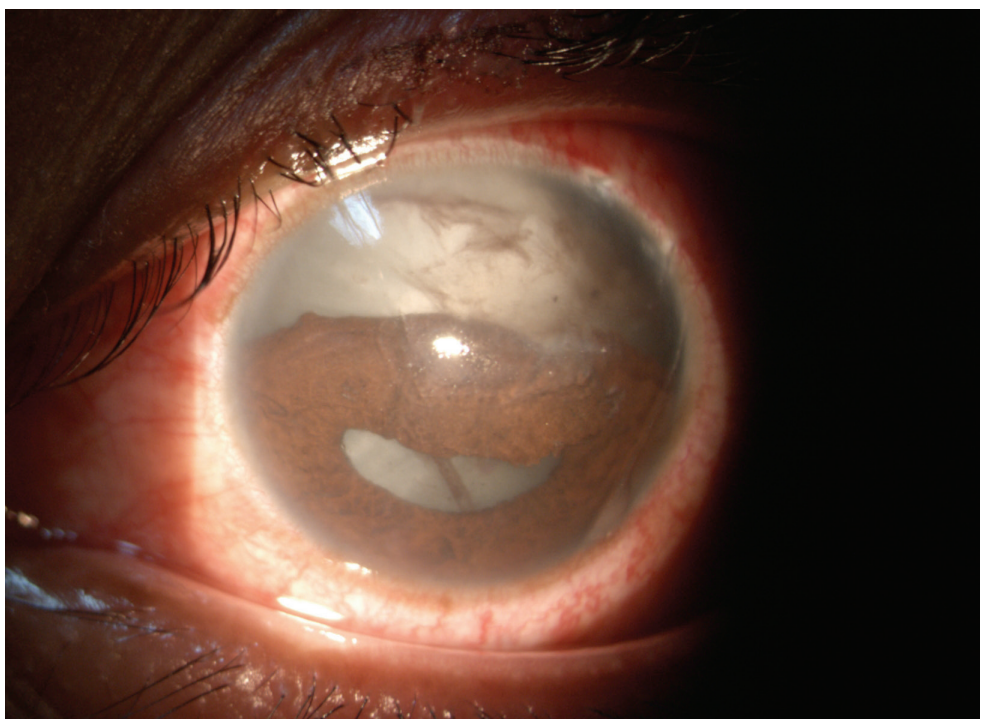

Fig. 1. Left eye anterior segment photo showing large iridodialysis extended from 9 to 3 o'clock with corectopia and breached anterior capsule superiorly. 

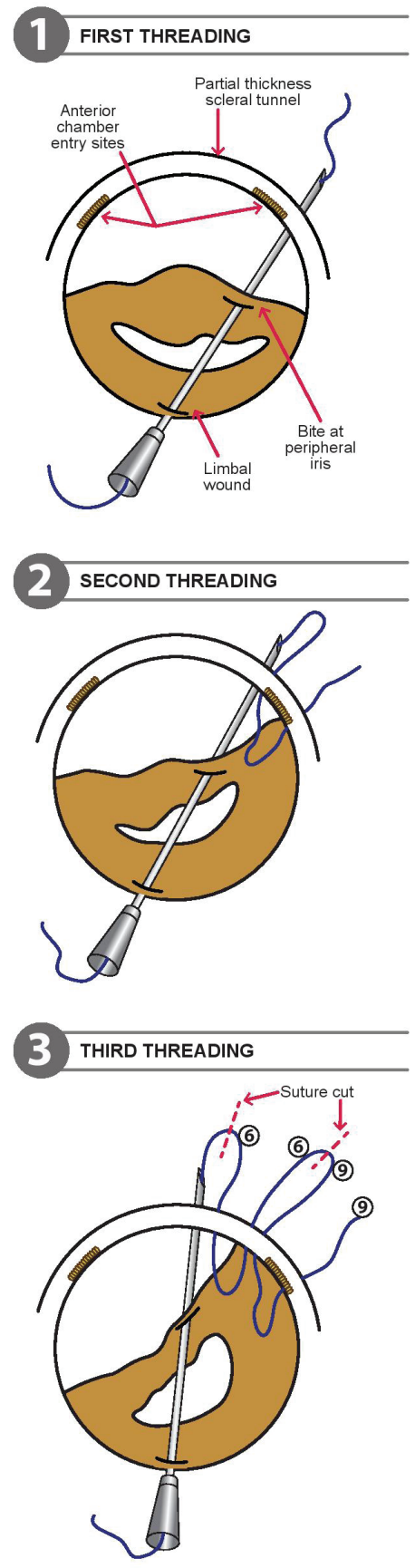

\section{Surgical technique}

Surgery was performed under general anesthesia. Our first aim was to do lens aspiration. A limbal-based conjunctival peritomy was done from 9 o'clock to 3 o'clock, in preparation for both lens aspiration and iridodialysis repair. A partial thickness scleral tunnel was created along the area of the iridodialysis from 9 o'clock to 3 o'clock, approximately $1.5 \mathrm{~mm}$ from the limbus. The anterior chamber was entered at 10 o'clock (main wound) and at 1 o'clock (paracentesis port) with a $15^{\circ}$ microsurgical ophthalmic knife. Viscoelastic gel was injected to deepen the anterior chamber and separate the iris from the anterior capsule and the crystalline lens. Lens aspiration was performed using the manual Simcoe. A superior breach of the posterior capsule was noted when finalizing the lens aspiration, and the procedure continued with anterior vitrectomy. After the lens aspiration and anterior vitrectomy were completed, we continued with the iridodialysis repair. We started by threading a 10/0 polypropylene suture through a 26 gauge, 1.5-inch long, straight hypodermic needle. The needle with the suture entered the anterior chamber via the inferior limbal wound at the 6 o'clock position and passed through the peripheral edge of the iris at the 9 o'clock position, at the site of the iridodialysis. It exited the anterior chamber through the scleral tunnel. The suture at the tip of the needle was pulled out approximately $2 \mathrm{~cm}$ and held with artery forceps.

Fig. 2. Illustration of passage of the 10-0 polypropylene suture from peripheral iris to scleral tunnel inside out and forming multiple suture loops. The suture loops laid over the scleral bed were cut and tied. 


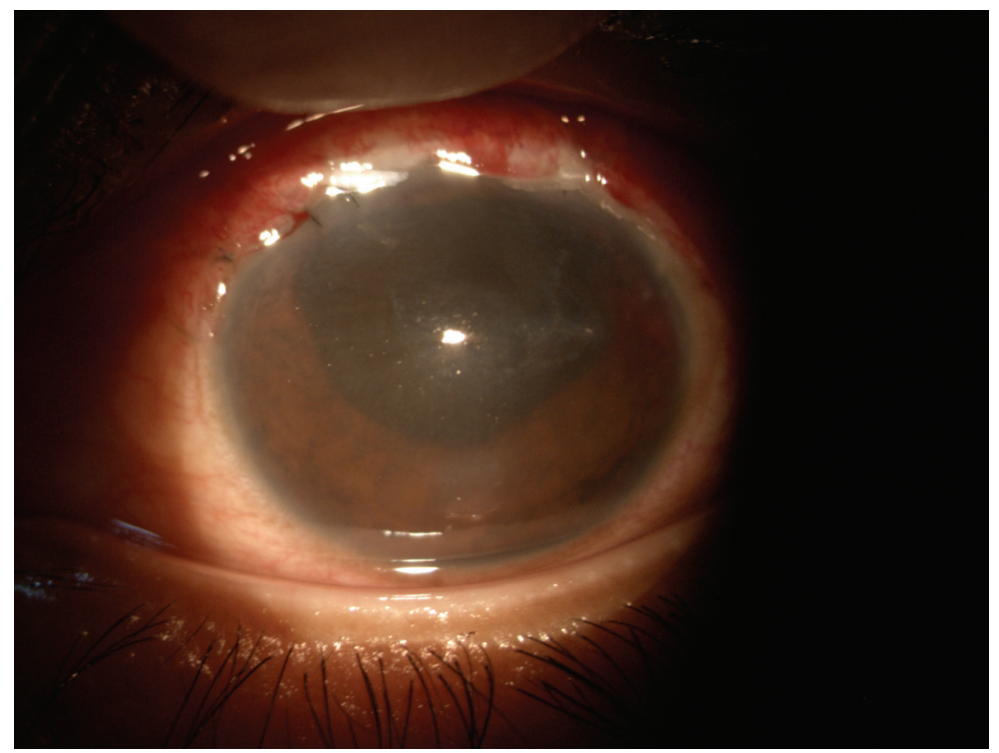

Fig. 3. Day 1 postoperative of the same eye after iridodialysis repair and lens aspiration.

The needle was pulled into the anterior chamber and took up another bite about 1 clock hour apart. The needle was externalized with the same method. A suture loop was created, and the needle was pulled into the anterior chamber again, taking up another bite on the edge of the iris (Fig. 2). This procedure was repeated until the suture loops were created along the iridodialysis. The loops were cut and tied. Precautions were taken to correctly match the ends of the threads before tying the knots. The knots were buried in the scleral tunnel. The eye was left aphakic. The closure of the conjunctival flap was done with 10/0 nylon. Intracameral carbachol solution $0.01 \%$ was administered (Fig. 3).

\section{Discussion}

Traumatic iridodialysis repair, lens aspiration, and anterior vitrectomy for a traumatic cataract with a breached anterior and posterior capsule rent in the same setting could present a surgical challenge. In the case presented, lens material that escaped from the breached anterior capsule obscured the view of the anterior chamber. Thus, lens aspiration was performed in the early stage of the surgery. There are several techniques reported in the literature for iridodialysis repair. These are categorized into open- and closed-chamber techniques. The open-chamber technique requires the creation of a self-sealed limbal incision or a scleral tunnel incision. 
The sewing machine technique was first proposed for iridodialysis repair by Kumar et al. in 2014. ${ }^{1}$ This technique is relatively easy and has a short learning curve. It is safe due to minimal manipulation and surgical instrumentation. It can be used for large iridodialysis repairs and provides good cosmetic results postoperatively. This technique requires burying multiple suture knots in the sclera. Thus, it may cause suture-related erosion and infection. In our case, the sewing machine technique was modified to accommodate iridodialysis repair with an associated anterior segment complication.

We reviewed other techniques proposed in the literature for repairing a large iridodialysis. Pandav et al. described a slightly different technique for iridodialysis repair, which has been named the "Cobbler's technique". ${ }^{2}$ In this technique, multiple loops of sutures are formed and laid over the scleral bed. The uniqueness of this technique is that the free end of the suture passes through the loops and is tied to form a single knot. This technique, which has been described as easy, can be used for a large iridodialysis repair and may reduce suture-related complications. Silva et al. described a similar single knot technique, but they used the auxiliary anchoring suture, which is passed inside the loop to temporarily secure the loop and prevent slippage. It is slightly time-consuming and requires extra sutures compared to the Cobbler's technique, but it may provide a more secure foundation for the loop intraoperatively. ${ }^{3}$

Other techniques for iridodialysis repair include the knotless technique proposed by Voykov et al. ${ }^{5}$ The polypropylene suture is secured in the sclera using a zigzag intrascleral suture (z suture). This technique can prevent suture-related erosion and infection, but it is more technically demanding. These techniques were not chosen for our case due to the possibility of adding complexity to a surgery that required lens aspiration at the same time.

The original sewing machine technique described by Kumar et al. involves creating a $2 \mathrm{~mm}$ long scleral tunnel with a corneal paracentesis wound away from the site of the iridodialysis. However, in our case, we modified the technique by creating a $1.5 \mathrm{~mm}$ long scleral tunnel and entering the anterior chamber through the same scleral tunnel at the 10 o'clock and 1 o'clock areas for the lens aspiration and paracentesis. No additional corneal wound was created. We believe that a shorter scleral tunnel provides an advantage for surgical manipulation in the anterior chamber, especially for a post-traumatic injury with multiple anterior segment complications. More importantly, the shorter scleral tunnel was still able to cover the suture knots adequately. Compared to other available techniques, the modified sewing machine technique is easily reproducible and requires a shorter learning curve. In conclusion, the modified sewing machine technique for iridodialysis repair, anterior vitrectomy, and lens aspiration in a single setting is possible and safe, providing a good anatomical outcome. 


\section{References}

1. Kumar KVR. Sewing Machine Technique for Iridodialysis Repair. Delhi Journal of Ophthalmology. 2014(24):248-251.

2. Pandav SS, Gupta PC, Singh RR, et al. Cobbler's Technique for Iridodialysis Repair. Middle East Afr. J. Ophthalmol. 2016;23(1):142-144.

3. Silva JL, Povoa J, Lobo C, Murta J. New technique for iridodialysis correction: Single-knot sewing-machine suture. J Cataract Refract Surg. 2016;42(4):520-523.

4. McCannel MA. A retrievable suture idea for anterior uveal problems. Ophthalmic Surg. 1976;7(2):98103.

5. Voykov B. Knotless technique for iridodialysis repair. Clin Exp Ophthalmol. 2016;44(2):135-136.

6. Bardak Y, Ozerturk Y, Durmus M, Mensiz E, Aytuluner E. Closed chamber iridodialysis repair using a needle with a distal hole. J Cataract Refract Surg. 2000;26(2):173-176.

7. Şengül Özdek MCO. A Simple Surgical Technique for Repair of Iridodialysis. Turk J Med Sci. 2009(39):317-319. 